\title{
Social Representations and Ideology: Theories of Common Sense About COVID-19 Among Middle-Class Brazilians and Their Ideological Implications
}

\author{
Luiz Gustavo Silva Souza ${ }^{a}$, Emma O’Dwyer ${ }^{\mathrm{b}}$, Sabrine Mantuan dos Santos Coutinho ${ }^{\mathrm{a}}$, Sharmistha Chaudhuri ${ }^{\mathrm{b}}$, \\ Laila Lilargem Rocha ${ }^{a}$, Luciane Pessanha de Souza ${ }^{a}$ \\ [a] Department of Psychology, Fluminense Federal University, Campos dos Goytacazes, Rio de faneiro, Brazil. [b] Department of Psychology, Kingston University, \\ London, United Kingdom.
}

Journal of Social and Political Psychology, 2021, Vol. 9(1), 105-122, https://doi.org/10.5964/jspp.6069

Received: 2020-10-12 • Accepted: 2021-01-22 • Published (VoR): 2021-02-19

Handling Editor: Cliodhna O'Connor, University College Dublin, Dublin, Ireland

Corresponding Author: Luiz Gustavo Silva Souza, Department of Psychology, Fluminense Federal University, Rua José do Patrocínio, n. 71, Centro, Campos dos Goytacazes, RJ, CEP 28030-130, Brazil. E-mail: souzaluiz@id.uff.br

\begin{abstract}
The COVID-19 pandemic has affected the lives of billions of people worldwide. Individuals and groups were compelled to construct theories of common sense about the disease to communicate and guide practices. The theory of social representations provides powerful concepts to analyse the psychosocial construction of COVID-19. This study aimed to understand the social representations of COVID-19 constructed by middle-class Brazilian adults and their ideological implications, providing a social-psychological analysis of these phenomena while the pandemic is still ongoing. We adopted a qualitative approach based on semi-structured in-depth interviews conducted online in April-May 2020. Participants were 13 middle-class Brazilians living in urban areas. We analysed the interviews with thematic analysis and a phenomenological approach. The social representations were organised around three themes: 1) a virus originated in human actions and with anthropocentric meanings (e.g., a punishment for the human-led destruction of the environment); 2) a dramatic disease that attacks the lungs and kills people perceived to have "low immunity"; and 3) a disturbing pandemic that was also conceived as a correction event with positive consequences. The social representations included beliefs about the individualistic determination of immunity, the attribution of divine causes to the pandemic, and the need for the moral reformation of humankind. The discussion highlights the ideological implications of these theories of common sense. Socially underprivileged groups are at greater COVID-19-related risk, which the investigated social representations may contribute to conceal and naturalise.
\end{abstract}

\section{Keywords}

COVID-19, pandemic, infectious disease, social representations, ideology, attribution of causality, cognitive polyphasia

\section{Resumo}

A pandemia de COVID-19 afetou o cotidiano de bilhões de pessoas em todo o mundo. Indivíduos e grupos foram levados a construir teorias de senso comum sobre a doença para se comunicarem e orientarem suas práticas. A teoria das representações sociais fornece valiosos conceitos para analisar a construção psicossocial da COVID-19. Este estudo procurou compreender as representações sociais da COVID-19 construídas por brasileiros adultos de classe média e suas implicações ideológicas, oferecendo uma análise sociopsicológica desses fenômenos enquanto a pandemia ainda está em curso. Adotamos uma abordagem qualitativa baseada em entrevistas semiestruturadas em profundidade, realizadas em abril e maio de 2020. Os participantes foram 13 adultos de classe média que viviam em áreas urbanas. Analisamos as entrevistas com análise temática e análise fenomenológica. As representações sociais estavam organizadas em torno de três temas: 1) um vírus causado por ações humanas e com sentidos antropocêntricos (por exemplo, a ideia de que o vírus é uma punição pela destruição do meio-ambiente); 2) uma doença dramática que ataca os pulmões e mata 
pessoas percebidas como portadoras de "baixa imunidade"; e 3) uma pandemia perturbadora, também concebida como um evento de correção e aprendizado com consequências positivas. As representações sociais incluíam crenças sobre a imunidade como característica individual, a atribuição de causas divinas para a pandemia e a necessidade de reforma moral da humanidade. A discussão ressalta as implicações ideológicas dessas teorias de senso comum. Grupos empobrecidos e marginalizados apresentam maiores riscos relacionados à COVID-19, riscos que as representações sociais investigadas podem contribuir para esconder e naturalizar.

\section{Palavras-Chave}

COVID-19, pandemia, doença infecciosa, representações sociais, ideologia, atribuição de causalidade, polifasia cognitiva

\section{Non-Technical Summary}

\section{Background}

At the end of 2019, a new virus emerged, SARS-CoV-2, popularly known as 'coronavirus'. Coronavirus is highly infectious and causes a respiratory disease, COVID-19, that can lead to severe symptoms and death. In 2020, the World Health Organisation declared COVID-19 a pandemic, that is, a new disease that has spread worldwide. At the time of writing, COVID-19 has caused more than two million human deaths all over the world. The pandemic has also caused significant disruption of everyday life. Since person-to-person is the main transmission route of the virus, social isolation and distancing became crucial public health measures. Many countries implemented the lockdown of cities and non-essential services, causing a substantial slowdown of economic activity. Brazil is one of the worst affected countries, with the second-largest number of coronavirus-related deaths at the time of writing. Underprivileged groups, for example, the working classes and black population in Brazil, are at greater COVID-19-related risk because of historical and social factors. They have a lower capacity to mobilise resources to prevent diseases and promote health, higher prevalence of chronic diseases, and a lower capacity to adhere to social isolation measures. It is important to understand how Brazilians perceived the emergence of the coronavirus, the spread of the pandemic and how they articulated these objects in theories of common sense (social representations). Previous research has shown that the way we construct theories of common sense about an object, for example, a new disease, has important implications for the ways we guide our practices, perceive ourselves and other social groups. Theories of common sense include ideology, that is, the use of ideas to establish or sustain social inequalities.

\section{Why was this study done?}

We conducted this study to understand the theories of common sense about COVID-19 constructed by middle-class Brazilian adults. We aimed to know how these 'theories' depicted relevant others, especially the underprivileged social groups. We also sought to understand if and how these 'theories' concealed and naturalised social inequalities and exploitation (that is, if and how they manifested ideological functions).

\section{What did the researchers do and find?}

We interviewed thirteen middle-class Brazilian adults living in urban areas. The small number of participants allowed us to explore their beliefs in depth. We analysed the interviews with methods that showed the participants' shared ideas whilst maintaining the richness of individual perceptions. We found that participants attributed the origin of the coronavirus to human actions (for example, the destruction of the environment and the "exotic" animal eating practices of the Chinese). They depicted COVID-19 as a 'dramatic disease' that attacks the lungs of those they considered to have "low immunity". They perceived immunity as an individual characteristic related to moral responsibility, self-care, and mental strength. They tended to see COVID-19 infections and mortality as a consequence of personal characteristics instead of social structures and inequalities. The participants perceived COVID-19 as a disturbing pandemic that threatens global health and economy. However, in their theories of common sense, the pandemic also has positive consequences: it is a necessary ordeal for the reformation of humankind. They considered that the pandemic would bring positive consequences such as more respect for rules, authority, and family values; the moral evolution of humankind towards spiritual "growth" instead of individualism and consumerism; and the 'purification' of those who will remain on Earth. 


\section{What do these findings mean?}

The perception of 'immunity as a personal characteristic' and 'the pandemic as a corrective event with positive consequences' may prevent individuals from recognising the social and historical factors that generate the greater COVID-19 vulnerability of underprivileged groups. Therefore, the investigated theories of common sense may be an obstacle to social critique and social change. The attribution of the origin of the coronavirus to what was perceived as "exotic" animal eating practices of the Chinese may also conceal the fact that the global (not only Chinese) animal industry is responsible for numerous infectious diseases and great mortality. Large sectors of the middle classes in Brazil and elsewhere may share some of the main elements of the theories of common sense that we investigated here. These analyses have implications for social actors interested in formulating a critique of the social and psychological responses to the COVID-19 pandemic.

The world is currently facing a pandemic of COVID-19, a respiratory disease caused by the SARS-CoV-2, a type of coronavirus (World Health Organisation, 2020b). 'The coronavirus' as it has been called (e.g., Jones et al., 2020) is highly transmissible. Some people infected with the virus may never develop any symptoms. However, the infection may also cause severe disease and death (World Health Organisation, 2020c). At the time of writing, the number of human deaths caused by COVID-19 has reached two million worldwide (BBC, 2021). Since person-to-person is the main transmission route of the virus, social isolation and distancing became crucial public health measures (World Health Organisation, 2020c). Many countries implemented the lockdown of cities, industries, transportation, and commerce, affecting the daily lives of billions of people and leading to a substantial slowdown of economic activity (Jones et al., 2020).

The origin of the SARS-CoV-2 is not completely understood. For the World Health Organisation, all scientific evidence indicates that the virus was not deliberately constructed and has a natural origin (World Health Organisation, 2020b). A large proportion of the first human cases were related to a wet market in the city of Wuhan (China), which may have been the origin of the outbreak or contributed to its amplification (World Health Organisation, 2020b). The transmission of SARS-CoV-2 occurs through contact with saliva and respiratory secretions from infected people, when they talk, cough or sneeze for example. The transmission is likely to occur when someone touches a contaminated surface and then touches their nose, mouth, or eye (World Health Organisation, 2020c).

Moscovici (1961) proposed the theory of social representations in his work about the appropriation of psychoanalysis by the Parisian public in the 1950s. At that time and place, psychoanalysis infected social thought much like a virus, its dissemination was rapid, and it concerned everyone (Moscovici, 1961). It was like a 'plague', as Sigmund Freud himself had supposedly told Carl Jung. Psychoanalysis was then a new object for the imagination of groups and individuals, who faced the urgent challenge of understanding what it was, how to see it in the real world, how to classify it and what to do with it.

SARS-CoV-2 is not a metaphorical but a real virus. As the pandemic quickly spreads, billions of people around the world are likely to experience the conditions described by Moscovici (1961) for the construction of social representations: 1) the dispersion of information (constantly updated by fast media services), 2) the focalisation (the impossibility of considering all the information at a given time leading individuals and groups to focus on specific ideas and images), and 3) the pressure to infer (the social pressure to construct theories of common sense about the relevant objects). We can define social representations as articulated sets of beliefs, images, and attitudes that correspond to the way a certain social group constructs the reality of a certain object, serving to (re)affirm identities and guide practices (Jodelet, 1989; Moscovici, 2000; Moscovici \& Hewstone, 1983).

Like Moscovici's (1961) investigation of the social representations of psychoanalysis, this study focuses on the active appropriation of expert knowledge by common sense. SARS-CoV-2 and COVID-19 are new objects that experts have introduced to common sense, through globalised media and social media (Apostolidis et al., 2020). Therefore, this study focuses on the passage from reified to consensual universes (Moscovici, 2000). Reified universes are instances through which individuals express authoritative knowledge (e.g., 'in the name of science') whereas consensual universes are instances where lay experiences constitute the knowledge's source of validation (Moscovici, 2000). However, the popularisation of expert knowledge does not replace common sense. Instead, individuals constantly experience a state of 
cognitive polyphasia (Jovchelovitch, 2008), i.e., the co-existence of heterogeneous types of rationality and the syncretic combination of fragmentary knowledge from different sources.

Individuals and groups construct social representations through the socio-cognitive processes of anchoring and objectification (Moscovici, 1961, 2000). Anchoring is the process of attributing meaning to an object according to deep-rooted cultural and group norms and beliefs. Objectification is the process of finding images capable of turning abstract concepts into visible realities. Thus, social thinking finds a meaning to an image and an image to a meaning (Moscovici, 1961, 2000). The overarching function of a social representation is to turn familiar the unfamiliar (Moscovici, 2000). Social representations allow individuals to communicate, guide their practices and construct or reinforce social identities (Jodelet, 1989).

These purposes may be particularly pressing when social actors face new diseases and pandemics (Moscovici, 1999). Previous research shows that the social representations of infectious diseases serve to protect not only the physical integrity of individuals but also the symbolic integrity of the ingroup (Eicher \& Bangerter, 2015). Eicher and Bangerter (2015) reviewed several studies that showed a process of othering in the construction of social representations of infectious diseases: outgroups are blamed for the origin of the disease and perceived as its preferential victims. These representations protect the ingroup from anxiety, ensuring a symbolic distance to illness and death (Eicher \& Bangerter, 2015).

Joffe (1995), for example, analysed the social representations of AIDS among homosexual men, when dominant representations depicted it as a divine punishment against homosexuality. She showed that participants blamed outgroups and/or endorsed conspiracy theories about powerful agencies to explicate the origin of the disease (Joffe, 1995). In a study about the social representations of the 2001 'bird flu' epidemic constructed by women in Hong Kong, Joffe and Lee (2004) verified that participants mostly blamed the Mainland Chinese for the disease, characterising them as greedy, unhygienic, immoral, and untrustworthy. As with these studies, Eicher and Bangerter (2015) identified typical common-sense beliefs about the origin of infectious diseases that coexist with scientific explanations: "divine punishment, immoral or unhygienic actions of out-groups, and malevolent actions of powerful groups" (Eicher \& Bangerter, 2015, p. 386).

Psychosocial analyses of COVID-19 are providing important insight into the human implications and consequences of the pandemic. Apostolidis et al. (2020) and Justo et al. (2020) advanced the heuristic value of the theory of social representations for the analysis of the crisis. The sociocognitive and affective construction of the 'new and threatening disease' is embedded in social identities, revealing different positions of individuals and groups in relation to outgroups and society (Apostolidis et al., 2020; Justo et al., 2020). Justo et al. (2020) highlighted different anchoring processes of COVID-19, as a health crisis or an economic crisis, depending on political affiliation. Páez and Pérez (2020) interpreted mediatic discourses about COVID-19 as ways of objectifying and anchoring the disease (e.g., the pandemic is 'like a war', and health professionals are 'heroes').

In this study, we focus on the ideological implications of the social representations of COVID-19. Social representations are not reducible to ideology, since the sociocognitive and affective dynamics of social representations are indispensable for the embodiment of ideology, its use in communication and the orientation of actions (Jodelet, 1991; Moscovici, 1991). Social representations have ideological effects when they contribute to social exclusion, e.g., of those considered mentally ill (Jodelet, 1989). Social representations do not mechanically derive from the socio-economic infrastructure and, more generally, they are not simply 'imposed from the outside' (Jodelet, 1991; Moscovici, 1999). They are the product of social creativity. Individuals and groups are active agents in the symbolic construction of reality and social transformation (Howarth et al., 2014). Not only do they receive the influence of ideology, but they also actively produce ideology when constructing social representations (Jodelet, 1991; Moscovici, 1991).

This is consonant with Thompson's (1990) concept of ideology, which we adopt in this paper. The author defines ideology as the "ways in which meaning serves to establish and sustain relations of domination" (p. 56), conceived as relations in which there is a systematic asymmetry of power. Power refers to the different capacities of individuals and groups to pursue their interests and define reality in the social world (Thompson, 1990). Differences in gender, age, and ethnicity, for example, not only social class, are the bases of asymmetrical relations and ideology (Thompson, 1990). In this paper, we focus on social class and indicate some ways in which the social representations of COVID-19 constructed by middle-class individuals may serve to (or be mobilised to) sustain relations of domination. 
Individuals are not passive recipients of ideology (Thompson, 1990). They reconstruct the social meanings and may use them to sustain relations of domination. However, they may also construct 'contestatory symbolic forms', i.e., meanings that challenge such relations (Thompson, 1990). This is consonant with the view that social representations reaffirm and/or resist dominant representations (Howarth et al., 2014).

It is paramount for the theory of social representations to consider the phenomenon of ideology because it allows the theory to explore the political implications of the construction of social reality (Howarth et al., 2014). Conversely, the study of social representations is essential for those interested in ideology because it reveals the sociocognitive processes and environments through which ideology is (re)created, embodied, and expressed (Jodelet, 1991; Moscovici, 1991).

\section{The Brazilian Context}

Brazil has one of the largest public health systems in the world (Brasil, 2012). The development of this system involved, however, power struggles that benefited the country's private health system (Paim, 2008). The country has experienced years of economic stagnation with growing levels of employment precarity, neoliberal reforms of labour and social security, and public spending freezes that have hit the impoverished sectors of the population particularly hard (Dantas, 2020). These reforms defunded the public health system and generated a growing financial gap in favour of private health services, which deliver care to a minority of the population and cannot provide a collective response to the COVID-19 pandemic (Dantas, 2020).

Individuals from higher social classes appear to have been the first affected by SARS-CoV-2 in Brazil (Santos, 2020). A series of position papers reveal, however, that the most impoverished classes, especially the black population, will suffer the most from the pandemic (Campos, 2020; Dantas, 2020; Goes et al., 2020; Santos, 2020). The black population suffers from class vulnerabilities worsened by racism. Structural racism in Brazil has its roots in the culture of slavery and is a crucial health determinant (Santos et al., 2020). For example, the prevalence of diabetes and hypertension in the Brazilian black population is double that of the white population (Goes et al., 2020).

Processes of health and sickness occur in structurally unequal social contexts. Social class and ethnicity are causes of health (Dantas, 2020; Martinez-Juarez et al., 2020; Santos, 2020). In comparison to privileged classes, the working classes have a lower capacity to mobilise resources to prevent diseases and promote health, higher prevalence of chronic diseases, a lower capacity to adhere to social isolation measures (crowded working and living conditions with lower access to sanitation), greater need to continually move around public spaces to meet basic needs and greater dependency on public transportation (Santos, 2020). In Brazil, there are around four times as many private ICU beds in comparison to the public ones (Dantas, 2020).

Following the recommendations of the World Health Organisation (World Health Organisation, 2020a), at the beginning of the pandemic, state and municipal governments in Brazil adopted the lockdown of non-essential services (G1, 2020; Magenta, 2020). The Brazilian federal government, however, has positioned itself against the lockdown, as well as individuals and groups from the business sector, perceiving that the slowdown of economic activity was harming their interests (Dantas, 2020). Prominent politicians and businesspersons have declared that the economy could not stop even at the cost of human lives (Campos, 2020).

We collected data for this study from the $26^{\text {th }}$ of April to the $9^{\text {th }}$ of May 2020. We started the procedure 40 days after the recording of the first death in Brazil caused by COVID-19 (on the $17^{\text {th }}$ of March) and 40 to 46 days after the implementation of lockdown measures by the initiative of Brazilian states (G1, 2020; Magenta, 2020). There was no unified national lockdown strategy (Magenta, 2020). In most places, only services considered essential could remain open. The measures included the closing down of schools, universities, services, and commerce in general (G1, 2020). Non-essential services remained closed until the end of the period of data collection.

The period of data collection for this study corresponds to the beginning of the 'first wave' of infections in Brazil. The country registered 12,400 coronavirus-related deaths on the $12^{\text {th }}$ of May (Magenta, 2020). Around the same period, on the $8^{\text {th }}$ of May, Italy, for example, registered 30,200 deaths (BBC, 2020). Brazil went on to be one of the worst affected countries in the world, with the second-largest number of coronavirus-related deaths (after the USA), with 209,847 deaths reported on the $15^{\text {th }}$ of January 2021 (BBC, 2021). 


\section{The Current Study}

Studies on social representations and COVID-19 have focused on the construction of representations in the media and social media (Apostolidis et al., 2020; Justo et al., 2020; Páez \& Pérez, 2020). The current study contributes to this growing literature focusing on the in-depth analysis of the representations constructed by a particular group and their ideological implications. It aimed to understand the social representations of COVID-19 constructed by middle-class Brazilian adults. The focus on the ideological implications may be particularly important in the present case, in which the pandemic has been heavily politicised worldwide and in Brazil (Apostolidis et al., 2020; Justo et al., 2020). This focus may also contribute to the theoretical articulation of the concepts of social representations and ideology, which may be useful for political psychology and social critique (Howarth et al., 2014).

\section{Method}

\section{Participants}

We adopted a qualitative approach and limited the number of participants to allow an in-depth exploration of their beliefs about COVID-19 (Snape \& Spencer, 2003). We used snowball sampling to recruit participants (Ritchie et al., 2003). We initially aimed to conduct twelve interviews, considering that the in-depth analyses of this number of interviews would suffice to reveal important features of the theories of common sense about COVID-19 and their ideological implications. Due to characteristics of the snowball sampling, one more interview was conducted, giving a final sample size of thirteen. All were Brazilian adults living in small cities in the Brazilian Southeast. The recruitment of participants followed criteria of gender, age, and social class. We ensured an equivalent distribution of participants regarding gender and age, as shown in Table 1.

Table 1

Numbers of Participants by Gender and Age

\begin{tabular}{lcc}
\hline Gender & $\mathbf{3 0}$ to 55 years old & 65 years old or older \\
\hline Female & 3 & 4 \\
Male & 3 & 3 \\
\hline
\end{tabular}

We did not aim to make comparisons by gender and age but simply to ensure a certain control of these variables. The purposive sampling targeted middle-class adults. This study did not include people under the age of 30 because they may be considered youngsters or young adults. We focused on participants who self-identified as adults, with established occupational activities, and for whom 'the youngsters' constituted an outgroup. We also wanted to include an equivalent proportion of elderly adults (in Brazil, generally defined as 65 years old or older) because they were described as the group most vulnerable to COVID-19. The gap between the two age groups served to establish a clear demarcation between the categories. We identified the participants as members of the middle-classes through initial contact with them during the recruitment process, based on cultural criteria (education level and occupation) and conditions of habitation. Although there were differences among the participants concerning social stratum (upper or lower middle-classes), all self-identified as members of the middle-classes.

\section{Procedure}

The data collection took place from the $26^{\text {th }}$ of April to the $9^{\text {th }}$ of May 2020. We met the participants through the online platforms Zoom, Google Meet, and Skype. Four Brazilian researchers conducted semi-structured interviews (Brinkmann, 2014) in Portuguese. The interview schedule began with an open question about how the participants perceived what was going on in the world. Then, the schedule included the following topics: 1) The perception of the coronavirus 
and COVID-19; 2) The origin of the coronavirus; 3) The spread of the coronavirus in Brazil; 4) The perception of the pandemic in its beginning and at the moment of the interview; 5) The sources of information about COVID-19; 6) The most surprising pieces of information about COVID-19. The mean duration of the interviews was 69.7 minutes $(S D=$ 28.6). The Kingston University Research Ethics Committee approved the research project (application number 1539). We followed all the guidelines for ethics in research with human beings in accordance with the Declaration of Helsinki. Prior to the interviews, each participant gave informed consent.

\section{Analysis}

We recorded the interviews in audio and transcribed them verbatim. Four of us analysed the data (in Portuguese) with thematic analysis (Terry et al., 2017). We used text-editing software to generate an analytic table for each interview. The table had two columns respectively labelled 'data', where we inserted the verbatim transcription in its entirety, and 'codes', where we coded all the empirical material. We identified the codes based on sentences or sets of sentences that varied in length, following the criterion of relevance to the research question (Terry et al., 2017). In this stage, we adopted the procedure described by Terry et al. (2017), i.e., we identified codes inductively as summaries of evident (semantic) and underlying (latent) ideas expressed by the participants ('China is taking advantage of the pandemic to sell ventilators' is an example of a semantic code, and 'Immunity as a result of personal virtue instead of social determinants' is an example of latent code). This initial coding process was the most extensive one and included inter-coder comparison. For each interview, two researchers independently coded the empirical material and then compared and discussed their findings to agree on a final version of coding. We subsequently identified four categories that comprehensively clustered the codes from all the interviews as follows: 1) the origin of the coronavirus, 2) the dissemination of the coronavirus, 3) the characteristics of COVID-19, and 4) the characteristics of the pandemic. We performed this second stage of coding collaboratively, as well as the identification of themes and subthemes, in synchronous online meetings, as a further measure to ensure credibility and reflexivity in the analysis.

Based on the same coding, we also applied a phenomenological approach (Bullington \& Karlsson, 1984) to the data to construct 'structures', i.e., summaries of each participant's perceptions of the research objects. Unlike the thematic analysis, this phenomenological approach considers the representations constructed by each participant individually (instead of treating the findings of a sample). It allowed the analysis to move between nomothetic and idiographic approaches. The combination of these two methods (thematic analysis and phenomenological approach) provided an understanding of the common elements of the investigated theories of common sense while maintaining the richness of individual perceptions. Furthermore, the phenomenological approach was used specifically to generate the findings on the heterogeneous processes of attribution of causality to the pandemic (summarised in the topic 'Findings', Table 3).

\section{Findings}

We refer to the participants with pseudonyms. Table 2 shows their sociodemographic information. In this section, all words, expressions, or paragraphs highlighted with quotation marks are verbatim extracts from the participants (translated into English by the first author). We provide contextualised interview quotations to illustrate our findings. We also integrate important words and expressions used by the participants into our description of the findings so that the report maintains the richness of the investigated representations.

The thematic analysis resulted in the identification of three themes. 1) The participants' beliefs about the origin of the virus and its consequences centred on human action. They represented the pathogen as an anthropocentric virus. 2) When referring to the disease, the participants highlighted the infection of vulnerable people and the more serious manifestations of COVID-19 leading to an undignified death. They represented COVID-19 as a dramatic disease. 3) They also represented COVID-19 as a pandemic threatening global health and economy. In their representations, however, the pandemic also had a positive purpose, a human meaning. It was a crisis serving to improve humankind. 
Table 2

Participants (Pseudonyms) and Sociodemographic Information

\begin{tabular}{|c|c|c|c|c|c|}
\hline Participants & Gender & Age (y.o.) & Education & Work situation & Religion \\
\hline Anna & Female & 49 & Postgraduate & Partial at home & - \\
\hline Clara & Female & 55 & Graduate & Full time at home & Evangelical \\
\hline Elton & Male & 68 & Postgraduate & Retired & Spiritism \\
\hline Hugo & Male & 68 & Graduate & Retired & Agnostic \\
\hline Iris & Female & 78 & Primary & Retired & Evangelical \\
\hline Julia & Female & 80 & Primary & Retired & Catholic/Spiritism \\
\hline Lucas & Male & 52 & Postgraduate & Full time at home & Candomblé \\
\hline Margaret & Female & 78 & Secondary & Retired & Spiritism \\
\hline Michelle & Female & 50 & Secondary & Full time at home & Christian \\
\hline Melanie & Female & 76 & Primary & Housewife & Evangelical \\
\hline Nicolas & Male & 69 & Postgraduate & Retired & Christian \\
\hline Roger & Male & 45 & Graduate & Full time at home & Spiritism \\
\hline William & Male & 30 & Secondary & Partial at the workplace & Christian \\
\hline
\end{tabular}

\section{An Anthropocentric Virus}

The participants claimed to have acquired information about COVID-19 from various experts through the media and social media. They mentioned numerous hypotheses to explicate the emergence of the coronavirus. Their beliefs shared a latent common anthropocentric thread. The virus was mostly depicted as anthropogenic and consequential for humankind. The participants referred to the following ideas (subthemes in italics) underpinning this common thread: the destruction of the environment, the mutations allowing the virus to infect humans, the practices and intentions of the Chinese, and the spiritual or divine origin of the virus.

\section{The Destruction of the Environment and the Mutations of the Virus}

Humans are destroying the environment, causing deforestation, pollution, and species extinction. Hence, they are "guilty" of the emergence of the virus (all words and expressions highlighted with quotation marks, such as "guilty" in the previous sentence, are verbatim extracts from the participants). Some participants stated that the coronavirus originated from natural causes such as "mutations" allowing it to infect humans. It is a previous "flu virus" that "got stronger naturally" (Michelle), an "old coronavirus" that has become "more aggressive" (Margaret), "a mutation of H1N1", or of the "swine flu" (Nicolas).

\section{The Practices and Intentions of the Chinese}

Participants often interweaved these ideas with beliefs about the practices and intentions of the Chinese. In their opinion, the coronavirus might have originated from the eating practices of the Chinese that they considered "weird" and "outrageous": they eat "wild animals", "anything that moves", "cockroaches, rats, insects, bats, dogs, cats". In the following extract, one of the participants associated these eating practices with the large Chinese population:

"The population in China is enormous and the Chinese are a people kind of... you know that they have weird eating habits, right. They eat bats. They eat rats, cockroaches. [...] because it is a lot of people, I think they resort to that so they can have food for everyone" (Julia).

For some participants, Chinese people also did not practice adequate hygiene, which may also have contributed to the emergence of the coronavirus. Participants perceived China to have "too many people" and cities "full of waste". The Chinese political system and government, perceived as communist and authoritarian, were also to blame. The Chinese government was negligent and took too long to lock down the region where the virus originated. Some participants mentioned the idea (and some endorsed it) that the Chinese intentionally created the virus. Chinese scientists created the virus in a laboratory aiming to "kill other viruses", "run tests", or produce medications or vaccines. However, they "lost control" of the virus and generated the pandemic. For one of the participants (Julia), their intentions were "evil": 
the Chinese intentionally spread the virus to make the world "go bankrupt" and "buy [cheap] the companies". In her opinion, China also wanted to sell masks, ventilators, and eliminate part of its elderly population because they are "an expense".

\section{The Spiritual or Divine Origin of the Virus}

Participants often combined these materialistic explanations with spiritual or divine ones. According to one of the participants (Elton), the virus was created by humankind's negative "mental field" which resulted from its accumulated moral flaws. Participants stated that God had created the virus or allowed it to come to existence aiming to "repair the world", transform people, and "unite the families" (Julia). For Melanie, God sent the virus because of humankind's "disobedience" and arrogance. Iris considered that the world was full of "evil", "criminals", "assassins", "paedophiles", "drug dealers", and that the pandemic was God's way to correct the mistakes of humankind. According to Julia, God was "sorting tares from wheat" (a biblical expression; 'tares' means 'weeds'). Julia referred to the separation of "materialist" people from 'good' people.

\section{A Dramatic Disease}

\section{The Uncontrollable Spread and the Fragile Victims}

The representation of COVID-19 as a dramatic disease stemmed in part from the perception of its uncontrollable spread and fragile victims. The participants represented the transmission of the coronavirus expressing three ideas (subthemes in italics): the invisible saturation of the air with the coronavirus, the action of the virus, and the action of careless contaminated people. The air becomes saturated with the virus because of "droplets of saliva" and "suspended little drops". One of the participants (Margaret) stated that the droplets may be more or less "robust", causing symptoms respectively more or less serious. Differently to the "dengue mosquito" (well known in Brazil) that one can see and avoid, the coronavirus is "invisible", and could be "everywhere". Participants described the coronavirus as "powerful" and "resistant", anthropomorphically conferring agency to the pathogen.

Participants evoked images of a person who contaminated others through speaking, cough, sneeze, tears, or sweat. They described the "asymptomatic", the person who has the virus but does not have symptoms of COVID-19 and infected others through their carelessness, as a source of anxiety. The description of the transmission process was interwoven with the prescription of behavioural norms such as respecting social distancing, washing hands, and using masks.

The participants also described the victims of COVID-19 that they perceived as more vulnerable: people with low immunity and low socio-economic status. Participants believed that different reactions to the disease were caused by "high" or "low" "immunity". They conceived "immunity" as an individual attribute. Elderly people and people with previous respiratory diseases were constructed as more vulnerable to COVID-19 because they naturally (biologically) had low immunity. However, the causes of low immunity could also be psychological or moral. Youngsters, for example, could also have low immunity, which explains why they could also die from COVID-19. Participants perceived youngsters to have low immunity because they are "immature", "undisciplined", they do not have "self-love", and, as one of the participants (Iris) stated, because of their "immoralities". In the following extract, another participant associated immunity to emotional maturity and self-care:

"Normally, youngsters do not eat very well, right, [...] this is a concern of more mature people [...] [when the person] grows up emotionally and she becomes more intelligent, let's say, regarding this issue, right. [...] Sometimes, the use of a lot of alcohol [by youngsters], right... they smoke, sometimes they do not get proper sleep, right, confuse night and day. I think all of this alters the person's immunity" (Michelle).

Others would have "fewer defences" because they have a "very pessimistic psychological functioning, are negative and depressed" (Elton). In all these cases, participants depicted low immunity as an individual characteristic.

Participants' beliefs referring to low socio-economic status were not so omnipresent and coherent in the data. For two of them (Hugo and Lucas), "those who are poorer" were more vulnerable to COVID-19 because they do not have 
basic sanitation, nor the conditions to socially isolate. For another participant (Julia), however, "the populace" in the favelas were more vulnerable because "most of them" are "inattentive", "reckless", and "ignorant".

\section{The Attack to the Lungs and the Undignified Death}

The participants represented COVID-19 as a disease based on three ideas: COVID-19 is an attack to the lungs, it is a new and mysterious disease, and it causes a dramatic death. Participants compared COVID-19 to the common flu, and sometimes characterised it as a "stronger flu". They highlighted, however, the most serious manifestations of the disease as an attack to the lungs. They described COVID-19 as "drowning without water", a "terrible and desperate disease", that "destroys the lungs after the seventh day", the victim "dies in days", "in a few hours", or "in ten minutes". According to one of the participants (Julia), "if it goes to your lungs, you are history".

Participants also represented COVID-19 as a new and mysterious disease, about which even the scientists knew little. The virus was referred to as "creative" and the victims could have different reactions, unforeseen symptoms, which were discovered every day. There was no cure or vaccine for COVID-19, and it was not known if a contaminated person "acquires immunity".

Participants represented COVID-19 as a disease that causes an undignified death. Based on the media and social media, they evoked images with strong negative connotations: doctors having to choose who lives and dies, preferring youngsters to elderly people; people desperate for an ICU bed; families suffering because they could not even provide a "dignifying" or "decent" burial to their members; dead people packed in plastic bags which evoked the objectification of the human body as waste. One of the participants referred to these ideas as follows:

"[The most shocking thing] is the drama with which [the media] show the issue of the relatives... [It is] a double tragedy, right. First, [the death of a family member]... then, you cannot decently bury your relative, father, mother. Hence, the crisis in the mortuary agencies... the burial is something extremely dramatic" (Hugo).

Figure 1 depicts the participants' social representations of COVID-19 as a disease.

\section{Figure 1}

Representation of COVID-19 as a Disease

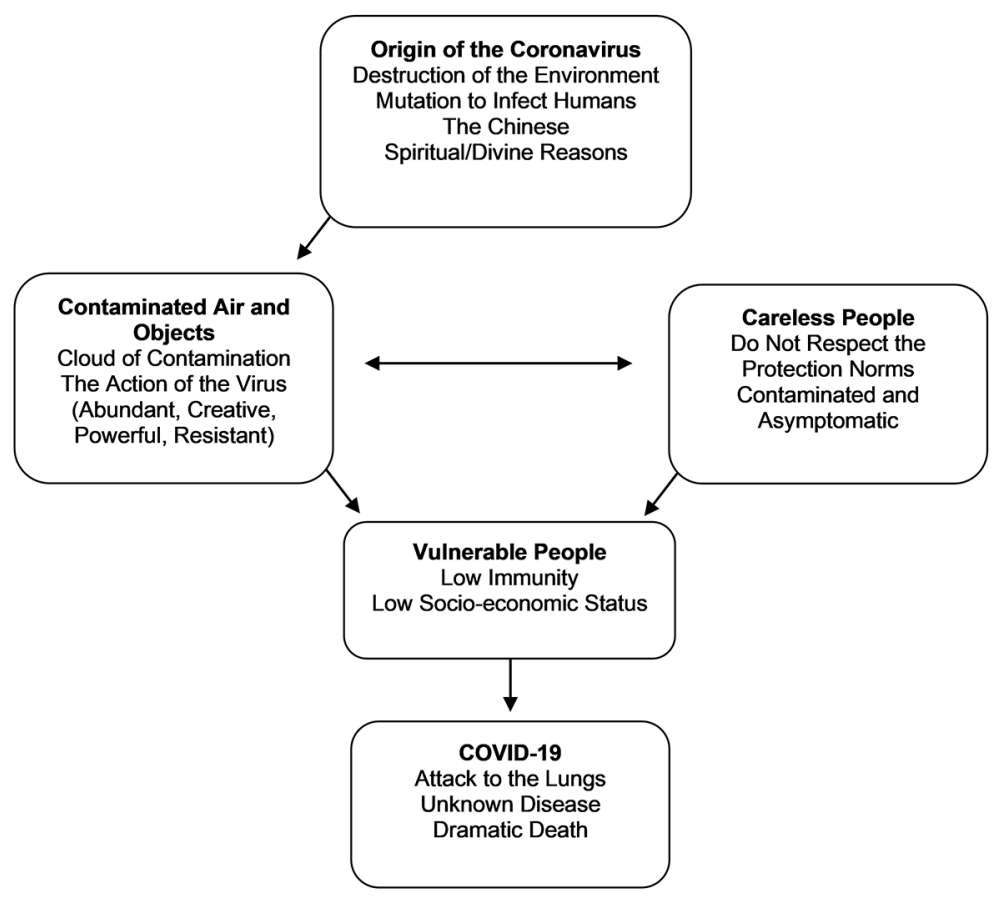


It is a process that initiates with the origin of the coronavirus, moves on to the circulation of the virus and the infection of people considered more vulnerable, and ends up in a serious attack to the lungs leading to a dramatic death.

\section{A Crisis Serving to Improve Humankind}

The participants represented COVID-19 not only as a disease but also as a pandemic, based on three ideas (subthemes in italics): the pandemic was a tragedy that threatens global health, a crisis that alters daily life, and a correction and learning event.

\section{A Tragedy That Threatens Global Health and Alters Daily Life}

The participants perceived the pandemic as a "tragedy" that was causing a lot of deaths and despair. According to Hugo, it was like a "tsunami" or a [thing of] "science fiction". For Julia, it was a "war" against an "invisible enemy", and her house was her "trench". Nicolas represented the pandemic as a war that did not destroy cities, but only lives, with "one person killing the other" via contamination. The pandemic was also represented as a crisis that disturbed daily life; altered relationships in families and work environments; caused the lockdown of cities and commerce, deserted streets, and the need to wear masks. It was a crisis that threatened the normality of society, economy, and public services. These representations mobilised explications of material nature, which contrasted with another prevalent thread in their representations (described below), characterised by moral and/or supernatural explanations.

\section{A Correction and Learning Event}

For the participants, the pandemic was also a correction and learning event or a warning. They presented elaborate theories of common sense to sustain these beliefs. It is important to describe some of these theories with further detail.

Based on his religion (Spiritism), one of the participants (Elton) believed that the pandemic was a tragedy that served to accelerate the evolution of the planet Earth. The destiny of human beings, according to him, is the moral evolution toward almost perfection (the closest possible to God). However, they commit many mistakes (moral flaws) and engender the need to learn from suffering. The participant thought that a great catastrophe such as a third world war could happen to operate the transition of the planet to a more evolved form. Therefore, he declared himself optimistic and serene in relation to the pandemic because it was a transition event which was not so drastic as he thought it could be. In his opinion, the pandemic will force people to "look inside themselves", face their anxieties and compulsions (for gambling, smoking, food, or sex), and morally evolve. Another participant (Margaret), who adhered to the same religion, stated that the pandemic was a warning from God so that humankind "wake up". According to her, human beings "only learn from pain".

For one of the participants who declared to be Evangelical (Iris), the pandemic happened with God's permission to oblige people to kneel, pray, and "convert to the will of God". For her, the pandemic took place to correct the lack of faith, materialism, and "immoralities" of people which "displease God". Among the "immoralities", the participant mentioned alcoholic beverages, bars, concerts, and the consumerism of expensive cars and clothes. For another participant (Melanie), also Evangelical, God was "very sad" with humankind because of its "disobedience, rebelliousness", "evil people", and those who did not want to "accept Jesus". Therefore, God allowed the pandemic, as a way of warning and teaching humankind. The pandemic was like the deluge, that took place because people disobeyed God. Similarly, a participant who declared herself to be Catholic and Spiritist (Julia) stated that, with the pandemic, God wanted to "shake up the Earth [...] so that people wake up". The purpose of the pandemic was to show that humans are destroying the environment and stop this destruction.

The belief that the pandemic was a warning did not necessarily depend on religious bases. One of the participants (Hugo), a self-declared agnostic, believed that the pandemic was a "lesson for the future" and society should prepare better to "natural tragedies". Another participant (Michelle) stated that the pandemic was a moral correction of the current society. In her perception, the world has become excessively licentious, has lost references of values and authority, and the pandemic was obliging people to reassess their behaviours and obey the rules. Therefore, the pandemic will bring more respect to "family values" and less rebelliousness. 


\section{The Causes and Meanings of the Pandemic}

The participants' theories of common sense, their explanations of the advent of COVID-19, involved not only beliefs about the operative causes of the phenomenon but also beliefs about its meanings. They sought to explain not only how the COVID-19 pandemic had appeared (its specific causes) but also what it meant to humankind. These meanings were perceived (latently and to different degrees) as broad causes of the pandemic. These broad (or cosmologic) explanations were characteristically anthropocentric. Table 3 , based on the phenomenological approach to the data, shows how each participant articulated the coexistence of specific and broad causes. The broad causes include justifications for the suffering caused by the pandemic as they imply its positive consequences. They depict the pandemic as a crisis serving to improve humankind.

\section{Table 3}

Operative (Specific) Causes of the COVID-19 Pandemic and its Meanings (Broad Causes) by Each Participant

\begin{tabular}{|c|c|c|}
\hline Participants & $\begin{array}{l}\text { Operative causes of COVID-19 } \\
\text { (Specific causes) }\end{array}$ & $\begin{array}{l}\text { The meanings of COVID-19 } \\
\text { (Broad causes) }\end{array}$ \\
\hline Anna & The virus originated from bats and disseminated amongst humans & $\begin{array}{l}\text { It was an opportunity that societies needed to learn preventive } \\
\text { behaviours }\end{array}$ \\
\hline Clara & The virus originated from the mutation of another virus & It was a moment for human beings to reflect on values \\
\hline Elton & $\begin{array}{l}\text { The virus emerged from the eating practices and lack of hygiene of the } \\
\text { Chinese }\end{array}$ & $\begin{array}{l}\text { It was a necessary ordeal for the moral evolution of the Earth and } \\
\text { humankind }\end{array}$ \\
\hline Hugo & Bats hosted the virus, and the Chinese eat "anything" & It was a warning for future "natural tragedies" \\
\hline Iris & $\begin{array}{l}\text { The Chinese created the virus with other purposes and lost control } \\
\text { over it }\end{array}$ & $\begin{array}{l}\text { It was so that people convert to God, abandon materialism and } \\
\text { immoralities }\end{array}$ \\
\hline Julia & $\begin{array}{l}\text { The virus originated from the eating practices of the Chinese or was } \\
\text { created by them }\end{array}$ & $\begin{array}{l}\text { It was a rebuke from God aiming to repair the world and humankind, } \\
\text { uniting the families }\end{array}$ \\
\hline Lucas & The virus came from bats that the Chinese have eaten & $\begin{array}{l}\text { It was a way to demonstrate that societies must finance health and } \\
\text { education }\end{array}$ \\
\hline Margaret & $\begin{array}{l}\text { The virus emerged from the mutation of other viruses caused by } \\
\text { various factors }\end{array}$ & $\begin{array}{l}\text { It was a warning from God for raising awareness of humankind and } \\
\text { fighting egoism }\end{array}$ \\
\hline Michelle & The virus was a flu virus that got stronger via natural processes & $\begin{array}{l}\text { It was a correction to the current licentious world, the lack of family } \\
\text { and leadership values }\end{array}$ \\
\hline Melanie & $\begin{array}{l}\text { The virus originated from the interference of human beings over } \\
\text { nature }\end{array}$ & $\begin{array}{l}\text { It was a warning from God against human rebelliousness and } \\
\text { disobedience }\end{array}$ \\
\hline Nicolas & $\begin{array}{l}\text { The Chinese might have created the virus, it may have originated from } \\
\text { eating practices or mutation }\end{array}$ & $\begin{array}{l}\text { It was a way for humankind to have awareness, unite in families and } \\
\text { think more about God }\end{array}$ \\
\hline Roger & $\begin{array}{l}\text { The virus emerged because the Orientals eat wild animals (e.g., } \\
\text { monkeys) }\end{array}$ & $\begin{array}{l}\text { It was a way of demonstrating the importance of health measures and } \\
\text { public health systems }\end{array}$ \\
\hline William & $\begin{array}{l}\text { The virus emerged from the eating practices of the Chinese or was } \\
\text { created by them in laboratory }\end{array}$ & It was a way for societies to learn disease prevention behaviours \\
\hline
\end{tabular}

Table 3 shows that, for Lucas and Roger, the pandemic occurred and became a serious problem because of deficiencies in public policies, especially in the health sector. The 'purpose' of the pandemic was to force societies to strengthen these policies. 
Participants revealed their beliefs about the positive consequences of the pandemic. Some of these consequences referred to individual behaviours, such as the adoption of preventive care. Other beliefs referred to large scale transformations such as scientific and technological advances in home office practices and telemedicine, for example. Amongst the beliefs about large scale transformations, there were those referring to the moral reform of humankind. After the pandemic and because of it, the planet Earth and humankind will morally evolve; mainly the "good" people, who value fraternity and fight egoism, will remain on Earth. The pandemic will cause an "awakening" to spiritual "growth" and the importance of family and friendships, rather than individualism and consumerism. It has united families and so people will "wake up" for the importance of family. Figure 2 summarises the social representations of COVID-19 as a pandemic.

Figure 2

Representation of COVID-19 as a Pandemic

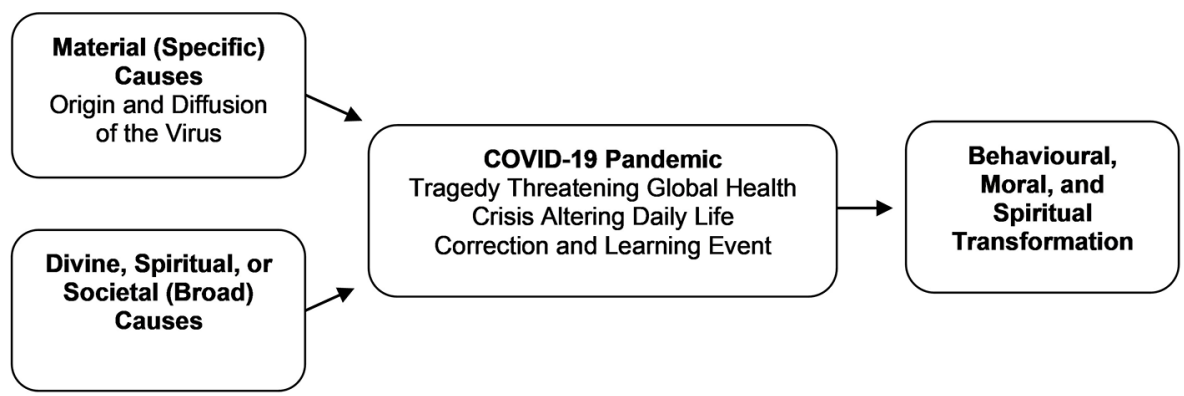

\section{Discussion}

This study aimed to understand the social representations of COVID-19 constructed by Brazilian middle-class adults. The findings show that perceiving COVID-19 was not only a matter of information and attitudes toward a single object but a process involving social representations, i.e., interwoven sets of cognitive and affective elements composing elaborate theories of common sense (Moscovici \& Hewstone, 1983). These theories articulated many objects: 'the coronavirus', the human body, immunity, vulnerability, age, material and spiritual causes of the pandemic and so forth. The investigated social representations were complex sets of beliefs, images, and attitudes, actively (re)constructed by individuals in their interface with society and culture (Jodelet, 1989; Moscovici, 2000).

This study also aimed to identify the ideological implications of the social representations of COVID-19. It is possible to find one such implication in the participants' perceptions about immunity as an individual characteristic dependant on moral correctness, 'mental strength', and maturity. These individualistic ideas are in sharp contrast with the analyses of social determinants of diseases and specifically COVID-19, including the influence of historical factors, social class, ethnicity, and structural racism for example (Dantas, 2020; Goes et al., 2020; Santos, 2020). They may lead individuals to blame members of socially disadvantaged groups for their COVID-19-related mortality. The working-classes and ethnic minorities in Brazil and elsewhere are at greater risk concerning the pandemic (Campos, 2020; Dantas, 2020; Goes et al., 2020; Martinez-Juarez et al., 2020; Santos, 2020; Santos et al., 2020). Ideology is the contextualised use of meanings to establish and maintain relations of domination (Thompson, 1990). The investigated social representations can have ideological effects when they 'blame the individual' for their "low immunity" and conceal the social determinants of SARS-CoV-2 infections and COVID-19 mortality.

One of the most important and pervasive elements in the participants' theories of common sense was the belief that the COVID-19 pandemic will ultimately have positive effects. The participants here had privileged social and economic conditions to stay at home, work from home, or protect themselves in general. As mentioned before, this is not the situation of the working classes and minorities in Brazil and elsewhere. The positive effects of the pandemic, the rethinking of values and practices, the improvement of humankind and society would come, therefore, at a great cost to underprivileged social groups. The concealment or naturalisation of such cost is an important ideological aspect of the 
investigated social representations. In the post-pandemic world, leaders and politicians may instrumentalise the belief about the positive outcomes with formulae such as 'it was for the best' or 'we come out of it stronger', which may then resonate with social representations of COVID-19 constructed by middle-class and working-class adults alike. Moscovici (1985) highlights how powerful leaders evoke powerful deep-rooted images and beliefs with ideological purposes. The investigated social representations (and their possible political mobilisation) have the ideological effects of naturalising the inequalities in housing, transportation, work, education, etc., i.e., in the material conditions of life of the socially underprivileged groups.

There is, however, a direr implication. Such social representations could lead individuals and groups to believe that a moral reform of humankind is happening precisely because the underprivileged groups and minorities are affected with greater mortality, a 'purification' theory similar to the belief that AIDS is a divine punishment to homosexuality (Joffe, 1995). This trend in the social representations was associated with the beliefs that God is "sorting tares from wheat" and only the "good" people will remain on Earth after the pandemic, as expressed by some of the participants and implied by others. It was possible to verify that at least one of the participants held explicitly derogatory beliefs about the working classes ("reckless", "ignorant"), blaming them for their vulnerability.

Other ideological implications can be found in the participants' theories about the origin of the virus. On the one hand, derogatory perceptions of Chinese people may lead to greater prejudice and discrimination against Asian ethnicities. The social representations indicate an alignment with anti-Chinese attitudes in a possible new world order structured by competition between China and the United States (Marcus, 2020). On the other hand, by blaming the 'exotic' Chinese eating practices, their causal attributions naturalised the global (not only Chinese) exploitation of non-human animals, an ideology referred to as carnism (Joy, 2010). Paim and Alonso (2020) show that the industrial production of meat and other animal-derived products is the source of numerous virus outbreaks and a major determinant of a post-antibiotic world with super-resistant bacteria. Approximately 700,000 deaths already occur per year due to antibiotic-resistant infections (Paim \& Alonso, 2020).

The researchers conducted the interviews when lockdown measures had recently been adopted, with evident disruptive consequences in Brazilian cities. During the interviews, we verified that the participants were considerably emotionally affected by the transformative events happening around them; the pandemic was, so to speak, a 'hot topic' demanding conversation and elaboration (pressure to infer, Moscovici, 2000). This emotional state is likely to be associated with the broad 'cosmologic' explanations that they elaborated to make sense of what was going on in the world, often involving nothing less than the future of humankind. Considering the participants' level of education and privileged middle-class position, it is striking to verify how 'unscientific' their social representations were or, more precisely, how far they went away or beyond scientific explanations. Moscovici (1999) highlighted that all modern societies produce these creative and intuitive theories of common sense and that social thinking in adults goes well beyond formal operative rationality.

The participants received information about COVID-19 from journalists and medical experts, i.e., actors inhabiting reified universes (Moscovici, 2000) speaking from socially legitimised positions of authority. However, the findings show that their perceptions were not restricted to legal, technical, or scientific information. They actively (re)constructed their social representations of COVID-19 in consensual universes (Moscovici, 2000), i.e., through interpersonal interactions in which the phenomenon acquired its meanings, operating the passage from standard to non-standard thinking (Moscovici \& Hewstone, 1983). The heterogeneous sources of knowledge (accurate and inaccurate scientific information, common sense, and religion) illustrate the process of cognitive polyphasia (Jovchelovitch, 2008). The purposive sample was weighted toward older adults. This may be related to the prominence of religious and spiritual elements in the investigated social representations.

The sociocognitive process of objectification (Moscovici, 2000) contributed to the construction of the investigated social representations. The participants evoked images to objectify ('see in the world') the origin of the coronavirus (destruction of the forests, crowded cities full of waste, the food in China, etc.); the nature of the coronavirus (an anthropomorphic entity that is creative and menacing); and the nature of the disease ("drowning without water", desperate families, burials with plastic bags, etc.). The objectification of COVID-19 as a dramatic disease allowed participants to distance themselves from the threatening new object, safely attributing its origin, circulation, and consequences to others (e.g., the Chinese, the "immoralities" of others, the careless infected people, and the people with "low immunity"). 
In the investigated social representations, the vulnerable groups were outgroups, the 'irresponsible youngsters', 'the mentally weak', and the working classes. This is consistent with the process of othering found in previous research about the social representations of infectious diseases (Eicher \& Bangerter, 2015; Joffe, 1995; Joffe \& Lee, 2004). The religious participants might have used their implied alignment to God to symbolically protect themselves from the disease (Eicher \& Bangerter, 2015).

The social representations performed their main function (Moscovici, 2000), taming the unfamiliar and threatening object and controlling the corresponding anxiety. These social representations also helped participants to sustain a positive view of their ingroup (Eicher \& Bangerter, 2015). As Eicher and Bangerter (2015) indicate, these analyses do not focus on the 'negativity' of social representations, i.e., their distance to expert knowledge, but in their 'positivity', i.e., the functions that they fulfil for individuals and groups. The three typical explanations for infectious diseases that Eicher and Bangerter (2015) highlight were present in this study (divine punishment, powerful agents, and the unhygienic outgroups). In the case of COVID-19, there was a fourth explanation, the belief that the pandemic is a correction and learning event destined to improve humankind.

The findings also illustrate the dual causality that characterises social representations (Moscovici \& Hewstone, 1983). A primary (spontaneous) causality is concerned with finalities while a secondary (categorical) causality deals with causes and effects (Moscovici, 2000). To explain COVID-19, the participants did not rely only upon efficient or 'objective' causes of the emergence of the coronavirus and its dissemination. They established its motives and purposes (primary causality), drawing conclusions about its meanings to themselves and, globally, to society and humanity. Social causality simultaneously mobilises objective causes and subjective motives, and individuals constantly alternate from the one to the other (Moscovici, 2000).

Deep-rooted common-sense beliefs, like the ones referring to the need for the moral reformation of humanity, are not negligible 'noises' in the process of attribution of causality but integral parts of the explanation and come to constitute the very phenomenon that individuals perceive (Moscovici, 2000). Another important deep-rooted belief referred to the unwholesome character of modern societies: the destruction of the environment, crowded cities full of waste, and deficient measures to prevent and treat diseases (the broad societal causes that participants referred to). Alongside beliefs about the flu, the youngsters, the working classes, and the Chinese, these deep-rooted common-sense beliefs about humanity and society participated in the construction of the investigated social representations through the sociocognitive process of anchoring (Moscovici, 2000). The representations anchored in traditional religious beliefs about the 'original sin' or 'fallen nature' of humankind (whose secular version was described by S. Freud - Moscovici, 1985) and traditional views about the 'artificiality and insalubrity' of modern societies (Herzlich, 1969/2005).

\section{Conclusions}

The investigated social representations of COVID-19 were organised around the themes of an anthropocentric virus, originated in human actions and with human meanings and consequences; a dramatic disease that attacks the lungs and kills people with "low immunity"; and a disturbing pandemic conceived as a correction and learning event with positive consequences for humankind. These social representations had important ideological implications. The pandemic of COVID-19 happens in a socially structured world in which cultural and economic factors determine the greater vulnerability of the working classes and minorities. The central beliefs about the individualistic determination of immunity and the positive consequences of the pandemic may function to maintain chronically asymmetric power relations in Brazilian society. Similar ideological patterns are likely to be found in the middle classes of other countries in Latin America and other parts of the world.

One of the most important limitations of this study is the small number of participants. Studies with larger samples may verify the presence of other elements of social representations. It is a study based on interviews and therefore has limited capacity to provide insight into social practices. The study did not systematically approach differences of age, gender, and political orientation, which may have important implications for the social representations of COVID-19 (Apostolidis et al., 2020; Justo et al., 2020). These limitations give indications that might be valuable for future studies.

Analyses of hegemony highlight the top-down trajectory of ideology, constructed by the dominant social classes and experts, and inculcated in the underprivileged majority (Moscovici, 1991). The social representations approach 
also allows the understanding of the bottom-up process of the construction of ideology. Social representations actively constructed by individuals in their consensual universes may serve as the bases for broader ideological discourses (Howarth et al., 2014). It is possible to consider the hypothesis that leaders and politicians will instrumentalise such social representations in a post-pandemic world and use the claim that 'the pandemic made society stronger' as part of ideological discourses.

The investigated social representations also included, however, contestatory symbolic forms, beliefs that challenged existing relations of domination (Thompson, 1990). They referred, for example, to the need to protect the environment and provide adequate health and education services to all social strata. Some participants at some moments recognised the greater vulnerability of the working classes and believed that collective measures should be taken to address this problem. As expected, such elements did not form a systematic social critique, but it is important to consider their presence. Furthermore, the purposes fulfilled by the social representations of COVID-19 cannot be completely assimilated into ideological functions. They allowed individuals to construct the symbolic reality of a threatening object and to deal with it, maintaining positive identities and guiding practices.

This study aimed to provide a social-psychological understanding of the symbolic construction of the COVID-19 pandemic and its ideological implications while the pandemic is still ongoing. The in-depth interviews allowed the identification of elaborate theories of common sense about the disease. The analysis revealed how these sets of beliefs, images, and attitudes may serve to sustain relations of domination. This study contributes to show that social representations and their dense sociocognitive and affective dynamics constitute one of the sources of ideology. Psychosocial interventions, e.g., on health and education, can tackle these complex representational dynamics. These interventions may perform a bottom-up critique of ideology, provide opportunities for the articulation of contestatory symbolic forms, tackle dominant social representations of marginalised and disadvantaged groups, and challenge existing social inequalities.

Funding: The authors have no funding to report.

Competing Interests: The authors have declared that no competing interests exist.

Acknowledgments: The authors have no support to report.

\section{References}

Apostolidis, T., Santos, F., \& Kalampalikis, N. (2020). Society against COVID-19: Challenges for the socio-genetic point of view of social representations. Papers on Social Representations, 29, X.1-X.14. Retrieved from

http://psr.iscte-iul.pt/index.php/PSR/article/view/551

BBC. (2020, May 8). Coronavirus: Italy death toll tops 30,000, highest in EU. BBC News. Retrieved from

https://www.bbc.co.uk/news/world-europe-52594570

BBC. (2021, January 15). COVID-19 pandemic: Tracking the global coronavirus outbreak. BBC News. Retrieved from

https://www.bbc.com/news/world-51235105

Brasil. (2012). Política nacional de Atenção Básica [National policy for primary health care]. Brasília, Brazil: Ministério da Saúde.

Brinkmann, S. (2014). Unstructured and semi-structured interviewing. In P. Leavy (Ed.), The Oxford handbook of qualitative research (pp. 277-299). New York, NY, USA: Oxford University Press.

Bullington, J., \& Karlsson, G. (1984). Introduction to phenomenological psychological research. Scandinavian fournal of Psychology, 25, 51-63. https://doi.org/10.1111/j.1467-9450.1984.tb01000.x

Campos, G. W. S. (2020). O pesadelo macabro da COVID-19 no Brasil: Entre negacionismos e desvarios [COVID-19 macabre nightmare in Brazil: Denials and ravings]. Trabalho, Educação e Saúde, 18, Article e00279111.

https://doi.org/10.1590/1981-7746-sol00279 
Dantas, A. V. (2020). Coronavírus, o pedagogo da catástrofe: Lições sobre o SUS e a relação entre público e privado [Coronavirus, the teacher of the catastrophe: Lessons about the Brazilian health system and the relations between the public and the private sectors]. Trabalho, Educação e Saúde, 18, Article e00281113. https://doi.org/10.1590/1981-7746-sol00281

Eicher, V., \& Bangerter, A. (2015). Social representations of infectious diseases. In G. Sammut, E. Andreouli, G. Gaskell, \& J. Valsiner (Eds.), The Cambridge handbook of social representations (pp. 385-396). Cambridge, United Kingdom: Cambridge University Press. G1. (2020, April 6). Coronavírus: Veja a cronologia da doença no Brasil [Coronavirus: See the chronology of the disease in Brazil]. G1. Retrieved from https://g1.globo.com/bemestar/coronavirus/noticia/2020/04/06/coronavirus-veja-a-cronologia-da-doenca-no-brasil.ghtml

Goes, E. F., Ramos, D. O., \& Ferreira, A. J. F. (2020). Desigualdades raciais em saúde e a pandemia da COVID-19 [Racial inequalities in health and the COVID-19 pandemic]. Trabalho, Educação e Saúde, 18, Article e00278110. https://doi.org/10.1590/1981-7746-sol00278

Herzlich, C. (1969/2005). Santé et maladie: Analyse d'une représentation sociale [Health and illness: Analysis of a social representation]. Paris, France: EHESS.

Howarth, C., Andreouli, E., \& Kessi, S. (2014). Social representations and the politics of participation. In P. Nesbitt-Larking, C. Kinnvall, T. Capelos, \& H. Dekker (Eds.), The Palgrave handbook of global political psychology (pp. 19-38). London, United Kingdom: Palgrave Macmillan.

Jodelet, D. (1989). Folies et représentations sociales [Madness and social representations]. Paris, France: PUF.

Jodelet, D. (1991). L'idéologie dans l'étude des représentations sociales [Ideology in the study of social representations]. In V. Aebischer, J.-P. Deconchy, \& E. M. Lipianski (Eds.), Idéologies et représentations sociales (pp. 15-33). Cousset, Switzerland: Delval.

Joffe, H. (1995). Social representations of AIDS: Towards encompassing issues of power. Papers on Social Representations, 4, $29-40$. Retrieved from http://psr.iscte-iul.pt/index.php/PSR/article/view/200

Joffe, H., \& Lee, H. Y. L. (2004). Social representation of a food risk: The Hong Kong avian bird flu epidemic. Fournal of Health Psychology, 9, 517-533. https://doi.org/10.1177/1359105304044036

Jones, L., Palumbo, D., \& Brown, D. (2020, June 30). Coronavirus: A visual guide to the economic impact. BBC News. Retrieved from https://www.bbc.com/news/business-51706225

Jovchelovitch, S. (2008). The rehabilitation of common sense: Social representations, science and cognitive polyphasia. Fournal for the Theory of Social Behaviour, 38, 431-448. https://doi.org/10.1111/j.1468-5914.2008.00378.x

Joy, M. (2010). Why we love dogs, eat pigs and wear cows: An introduction to carnism, the belief system that enables us to eat some animals and not others. San Francisco, CA, USA: Conari.

Justo, A. M., Bousfield, A. B. S., Giacomozzi, A. I., \& Camargo, B. V. (2020). Communication, social representations and prevention Information polarization on COVID-19 in Brazil. Papers on Social Representations, 29, X.1-X.18. Retrieved from http://psr.iscte-iul.pt/index.php/PSR/article/view/533

Magenta, M. (2020, May 13). Coronavírus: 10 gráficos para entender a situação atual do Brasil na pandemia [Coronavirus: 10 graphs to understand the current situation of the pandemic in Brazil]. BBC News. Retrieved from https://www.bbc.com/portuguese/brasil-52595760

Marcus, J. (2020, July 2). The Hong Kong crisis and the new world order. BBC News. Retrieved from https://www.bbc.com/news/world-asia-china-53263181

Martinez-Juarez, L. A., Sedas, A. C., Orcutt, M., \& Bhopal, R. (2020). Governments and international institutions should urgently attend to the unjust disparities that COVID-19 is exposing and causing. EClinicalMedicine, 23, Article 100376. https://doi.org/10.1016/j.eclinm.2020.100376

Moscovici, S. (1961). La psychanalyse, son image et son public: Étude sur la représentation sociale de la psychanalyse [Psychoanalysis: Its image and its public: Study on the social representation of psychoanalysis]. Paris, France: PUF.

Moscovici, S. (1985). L'âge des foules: Un traité historique de psychologie des masses [The age of the crowd: A historical treatise on mass psychology]. Brussels, Belgium: Complexe.

Moscovici, S. (1991). La fin des représentations sociales? [The end/aim of social representations?] In V. Aebischer, J.-P. Deconchy, \& E. M. Lipianski (Eds.), Idéologies et Représentations Sociales (pp. 65-84). Cousset, Switzerland: Delval.

Moscovici, S. (1999). Des représentations collectives aux représentations sociales: Éléments pour une histoire [From collective to social representations: Elements for a history]. In D. Jodelet (Ed.), Les représentations sociales (pp. 79-103). Paris, France: PUF.

Moscovici, S. (2000). Social representations: Explorations in social psychology. Cambridge, United Kingdom: Polity Press. 
Moscovici, S., \& Hewstone, M. (1983). Social representations and social explanations: From the 'naive' to the amateur scientist. In M. Hewstone (Ed.), Attribution theory: Social and functional extensions (pp. 98-125). Oxford, United Kingdom: Blackwell.

Páez, D., \& Pérez, J. A. (2020). Social representations of COVID-19. International fournal of Social Psychology, 35, 600-610. https://doi.org/10.1080/02134748.2020.1783852

Paim, C. S., \& Alonso, W. J. (2020). Pandemics, global health and consumer choices. Alfenas, Brazil: Cria.

Paim, J. S. (2008). Reforma Sanitária Brasileira: Contribuição para a compreensão e crítica [Brazilian Health Reform: A contribution to its understanding and critique]. Salvador, Brazil: EdUFBA.

Ritchie, J., Lewis, J., \& Elam, G. (2003). Designing and selecting samples. In J. Ritchie \& J. Lewis (Eds.), Qualitative research practice. A guide for social science students and researchers (pp. 77-108). London, United Kingdom: SAGE.

Santos, J. A. F. (2020). COVID-19, causas fundamentais, classe social e território [COVID-19, fundamental causes, social class, and territory]. Trabalho, Educação e Saúde, 18, Article e00280112. https://doi.org/10.1590/1981-7746-sol00280

Santos, M. P. A., Nery, J. S., Goes, E. F., Silva, A., Santos, A. B. S., Batista, L. E., \& Araújo, E. M. (2020). População negra e COVID-19: Reflexões sobre racismo e saúde [Black population and COVID-19: Reflections on racism and health]. Estudos Avançados, 34(99), 225-243. https://doi.org/10.1590/s0103-4014.2020.3499.014

Snape, D., \& Spencer, L. (2003). The foundations of qualitative research. In J. Ritchie \& J. Lewis (Eds.), Qualitative research practice: A guide for social science students and researchers (pp. 1-23). London, United Kingdom: SAGE.

Terry, G., Hayfield, N., Clarke, V., \& Braun, V. (2017). Thematic analysis. In C. Willig \& W. S. Rogers (Eds.), The SAGE handbook of qualitative research in psychology (pp. 17-36). London, United Kingdom: SAGE.

Thompson, J. B. (1990). Ideology and modern culture: Critical social theory in the era of mass communication. Cambridge, United Kingdom: Polity.

World Health Organisation. (2020a). Critical preparedness, readiness and response actions for COVID-19: Interim guidance 22 March 2020. United Nations. Retrieved from https://extranet.who.int/goarn/critical-preparedness-readiness-and-response-actions-covid-19

World Health Organisation. (2020b). Origin of SARS-CoV-2. United Nations. Retrieved from https://apps.who.int/iris/bitstream/handle/10665/332197/WHO-2019-nCoV-FAQ-Virus_origin-2020.1-eng.pdf

World Health Organisation. (2020c). Transmission of SARS-CoV-2: Implications for infection prevention precautions. United Nations. Retrieved from https://www.who.int/publications/i/item/modes-of-transmission-of-virus-causing-covid-19-implications-for-ipc-precautionrecommendations 